\title{
Impacts of US Reindustrialization on Chinese Manufacturing
}

\author{
Wenbin Zhao, Haiyan Yan, Hui Liu \\ The School of Management, Shanghai University of International Business and Economics, Shanghai, China \\ Email: cherry.kobe@qq.com
}

Received June 2014

\begin{abstract}
The hollowing-out degree of American local manufacturing enterprises has reached a rather high level due to the long-term off-shoring of the industries to other developing countries. Some U.S. companies started to show intentions to move their manufacturing back home-a strategy known as "re-shoring" since 2010. The re-shoring behavior in U.S. manufacturing has triggered much concern about U.S. Manufacturing Rebuilding. This article analyzes the key factors that may influence U.S. companies' re-shoring strategies. In the empirical part, regression formula is established to evaluate those potential influence factors and verify their significance.
\end{abstract}

\section{Keywords}

Reindustrialization, Influence, Manufacturing

\section{Introduction}

Since American president, Obama, formally sign US Manufacturing Enhancement Act in 2010, plenty of the Fortune Global 500 companies, such as Intel, Ford, have started to move their overseas manufacturing factories or offices back to the United States, what's more, also announced to the public that they would start to invest a huge amount of capital on the mainland in order to respond to the call of the government and raise the employment rate. Thus, capital returning to America is starting to appear.

In 2011, BCG company released a report named as American Manufacturing Reindustrialization-Why? This report mainly analyzed on the two kinds and tendencies of companies which will return to US. One is those new hi-tech enterprises with high value-added and advanced technology, while the other is the labor-intensive industries, which are likely to transfer from China to those developing countries with lower cost in the near future.

From another point of view, the manufacturing reindustrialization to America can be proved by data collected from Chinese Ministry of Commerce. In the data, obviously, the number of new US companies built in China for investment is decreasing gradually in recent 3 years by the average $6 \%$ which evidently shows the interest of US manufacturing on Chinese land has moved to other places. And the number of new enterprises created by all the other countries also got a sharp decrease, reaching 10\% in 2012. Though there may be some shortage on the data and no ideas about how large the reindustrialization scale will be, it still can be seen that the foreign in- 
vestment is truly falling. I think Chinese manufacturing, which is experiencing the adjustment on the producing policy, should attach importance to this potential phenomenon whether it's a flash in the pan or the tip of the iceberg. With the domestic industrial structure's updating and the increasing impact from those lower-cost emerging market like Vietnam or Malaysia, it is strongly urgent for China to change the order manufacturing ways and prompt to concentrate on those high value-added and technology industries rather than the large range's repeated construction and production which lead to the previous cut-throat competition. So, attention should be extremely paid to how much the US manufacturing reindustrialization influences on the domestic industries.

\section{Literature Review}

When it comes to the research on the theory of multinational companies’ disinvestment, Michael E. Porter (1976) mainly uses the industrial organization structure [1] to analyze the function. Boddewyn (1979) reverses the Eclectic Theory of International Production led by Dunning to point out the three deciding thresholds of foreign companies' disinvesting [2] from the host country. Besides the companies' own subjective factor, Hamilton and Chow (1993) also emphasize the influence of external environment [3] on disinvestment, such as macroeconomic conditions, industries' growth situation and so on. McDermott (1994) classifies the different kinds of foreign enterprises' withdrawing capital [4]. In his points, there exist two types of this behavior, offensive and defensive.

When researching on the degree of US manufacturing reindustrialization, Chen Xi (2012) emphasizes that there actually exist many unknown situations and obstacles [5] even though the returning will create and bring precious resources and new opportunities; Lu Yang (2013), however, points out that it's not true [6] that Chinese comprehensive labor cost has caught up with Britain or America though the domestic price really keeps sharp increasing these years. In addition, the reindustrialization, in fact, is a kind of inverse globalization, so it's becoming more and more difficult to completely accomplish it in a globalization environment. Other aspects, like the influence of reindustrialization, Mi Jianwei and Chen Qiang (2012) think that the action will mainly affect those Chinese industries [7], which own higher technology, by comparing the growth of foreign capital inflow in the 7 main manufacturing industries of Chinese and America.

In conclusion, US manufacturing reindustrialization can be explained by the multinational corporations' disinvestment on theory. Due to the short period of the phenomenon till now, not too many scholars choose this behavior as their research direction, so there are no more systematic research results or theory on the influence factors or the future expectation about reindustrialization.

\section{Impact of Reindustrialization on Chinese Manufacturing}

It occurs to be that Chinese manufacturing is likely to encounter the huge pressure on development in case the reindustrialization keeps its sustainable growing. On one side, domestic industrial construction and economic development make new technology requirements on the manufacturing which needs to accelerate the speed of industrial structure upgrade. On the other side, the goods with high quality and low price from the international market create a large strike on domestic market. Chinese producing industries will probably meet more difficulties with the reindustrialization tendency.

\subsection{Upgrade of Foreign Trade Friction}

American has carried out a serious of policies to enlarge the export competition in order to meet the Export-Oriented Growth proposed by government's Reindustrialization plan, and this change is estimated to have a great influence and challenge to Chinese manufacturing exports [8], especially to those middle and high quality productions which are exported to American. According to the forecast from BCG Company, reindustrialization will make American merchandise trade deficit get a dramatic decrease, even oil's situation may have a change because of the Shale Gas Evolution. Under the stricter and stricter trade protection policy in western countries, many Chinese industries, such as fine chemistry, equipment manufacturing, vehicles, bio-pharmaceuticals, electrical equipment and so on, have to face lots of furious trade frictions and disputes.

From the Vehicle Transportation in Table 1, trade surplus respectively reached $44.60 \%$, 35.79\% and $12.02 \%$ in the 3 years. Obviously, the growth rate was in a decline, which means that the surplus is likely to be reversed soon on some kinds of high quality production, from a certain extent. On the other hand, Chemical Engineering 
Table 1. Some Products’ Import and Export in 2008-2011 Unit: \$100,000,000.

\begin{tabular}{cccccccccc}
\hline \multirow{2}{*}{ Year/Classification } & \multicolumn{2}{c}{2008} & \multicolumn{2}{c}{2009} & \multicolumn{2}{c}{2010} & & 2011 \\
\cline { 2 - 10 } & $\mathrm{E}$ & $\mathrm{I}$ & $\mathrm{E}$ & $\mathrm{I}$ & $\mathrm{E}$ & $\mathrm{I}$ & $\mathrm{E}$ & $\mathrm{I}$ \\
\hline $\begin{array}{c}\text { Vehicle } \\
\text { Transportation } \\
\text { Chemical } \\
\text { Engineering }\end{array}$ & 706.97 & 397.54 & 600.91 & 429.47 & 888.74 & 655.95 & 1091.07 & 830.30 \\
\hline
\end{tabular}

Data collected from China Statistical Yearbook (E: Export I: Import).

is always a trade deficit, but it can be seen the rate is in a slowing phase in recent 3 years, reaching $91.56 \%$, $18.44 \%$ and $14.47 \%$. Related industries are making large efforts on this part of manufacturing, so the export growth rate is declining in the recent 2 years, $39 \%$ and $30 \%$.

Despite of the limited data collected, it is still evident that American reindustrialization really forms an influence on Chinese high-end manufacturing, as well as the production's exports.

\subsection{Technical Commanding Heights Is Not Easy to Break}

All the time, transfer of technology is an important mode of cooperation between China and transnational corporations [9]. This mode promotes knowledge diffusion and technology spillover, helps foreign corporations get desired production value, more important, makes China's related industries can learn overseas advanced technology and benefit from technology spillover. But after implementation of America's reindustrialization strategic idea, rely on advantage and leading position in patents, standard, technology, intellectual property and so on, America may establish technical barriers for China's manufacturer industry intentionally or unintentionally, [10] which leads to sluggish of development and update of China's manufacturer industry.

As transfer of Made in China to Invent in China, China is at the key point of manufacture industrial transformation and update, should strive to develop advanced manufacture industry with high additional value (new energy automobile, new energy material, aerospace manufacturing, electronic information, biological medicine, advanced equipment manufacturing, etc.), reform and improve traditional basic manufacture industry. When backwards transfer ${ }^{2}$ emerges from international market, advanced manufacture industry will go back to homeland of transnational corporations, which will prolong the time of China's related industries learn and develop from foreign advanced technology to a great extent and take a toll on China's manufacture industry.

As can be seen from the data in Table 2, foreign corporations number of these four industries are reducing gradually after 2009 , and totality reduced by $17 \%$ in 2011 . Of course this reduction can't be simply attributed to moving back to homeland of American or global corporations, but it is undeniable that the reduction will affect technology diffusion of high technology in China to a certain extent.

\subsection{Gap of Innovation Competitiveness Is Increasing}

According to related data, China's manufacture technology dependence on foreign technology is more than 50\%, which leads to obvious influence: As China's corporations have no ownership of key technologies, they have to pay many percent of products price to foreign patent owners, such as $30 \%$ of computer price, $20 \%$ of cellphone, $20 \%$ to $40 \%$ of NC machine tool.

Compared to developed countries, the relative added value of China's research and development fee is far behind. The rate of China's research and development fee to total output value is only $1.63 \%$, which indicates that China's input on research and development fee is still too little. The implementation of America's reindustrialization strategy will be based on a new wave of technological revolution, and has four advantages: distribution network is wide and reasonable, channel of information is unobstructed, trade is convenient, and market circumstances are friendly. These create market conditions for America's revive industry plan and production return of manufacture industry, and also will bring challenge and influence definitely for China's manufacture industry.

\subsection{Industry Influence Analysis}

America's manufacture industry backflow began from 2010 around. As can be seen from the data in Table 3, 
Table 2. Business condition of foreign high technology industry (number of corporations).

\begin{tabular}{ccccc}
\hline Industry/Year & 2008 & 2009 & 2010 & 2011 \\
\hline Total & 5442 & 5487 & 5393 & 4434 \\
Pharmaceutical manufacturing & 704 & 692 & 696 & 559 \\
$\begin{array}{c}\text { Aerospace vehicle manufacturing } \\
\text { Electronic and }\end{array}$ & 45 & 50 & 52 & 46 \\
$\begin{array}{c}\text { communication equipment } \\
\text { Electronic computer and } \\
\text { office equipment }\end{array}$ & 3387 & 3326 & 4243 & 427 \\
\hline
\end{tabular}

Data source: clear up according to China high technology industry statistical yearbook 2012

Table 3. Comparison of foreign investment growth percent about 7 main manufacture industries in China and America in 2011.

\begin{tabular}{cccc}
\hline Industry & Foreign investment growth in America (\%) & America investment growth in China (\%) & 15.7 \\
\hline Food processing & 5.7 & 5.5 & 17.7 \\
Metallurgy & 0.1 & 38.1 \\
Machinery & 28.9 & 12.9 \\
Chemical industry & 18.2 & -31.5 \\
Electrical equipment & 2.2 & -13.5 \\
IT electron & 2.3 & 36.7 \\
Transportation facilities manufacture & &
\end{tabular}

Data source: US Commerce Department website

America's chemical industry and electrical equipment that have high additional value get good graces of foreign investment, the investment growth percent reached $28.9 \%$ and $18.2 \%$ respectively in 2011. Most of America's investment in China was in steady growth, except electrical equipment and IT electron that reduced a lot. Especially, investment of electrical equipment was reduced by one third; on the other hand, electrical equipment was also the industry got foreign investment very much in America. So China's electrical equipment industry may be impacted in future. It indicates that if America backflow continue to expand, industries like chemical industry, electrical equipment and IT electron more likely being the leader.

As China's capability of independent innovation is very weak yet, development of electrical equipment manufacture industry and other related industries only depend on terminal equipment industry chain [11]. But terminal consumption equipment, such as PC and mobile phone, bear rising pressure from the customer demand obviously for now, show up features with very fast updating and development without plan, which leads to a dim view of integrated circuit industry's development. Take semiconductor manufacture in integrated circuit industry as example, there are some big features like very high technology cohesion, fast products updating, high production process requirements. Unfortunately, at this stage, at development direction of advanced technology and products, Chinese native corporations still have not enough strength to divide a piece of their own market in high technology products area.

Therefore, if the large-scale backflow trend comes out true, the international technical research and development corporations will delay the process of the newest technologies introduction to China's manufacture corporations. Especially for industries with high technology or high additional value, this influence will be more remarkable.

\section{Conclusions}

Although the convenience offered by America government produced a lot of effects on pushing corporations back to America to invest, cost pressure and market pull are the most important decisive factors in corporations' 
backflow decision about disinvestment from host country and investment back to America as corporations are profit-seeking.

This paper referred to the distribution of America's manufacture corporations in China, chosen communication equipment, computer and electronic products industries that include many America corporations, analyzed the influence to China's manufacture corporations caused by foreign corporations' disinvestment. Judging from the whole manufacture industry, large-scale backflow of America manufacture corporations will have no influence on attracting foreign investment of China's manufacture industry and the advantage of China compared to other developing countries in the short term, but will affect the China's long-term export to northern America.

\section{Acknowledgements}

Supported by New academic talents cultivation project for broad liberal-arts graduates in Shanghai local universities and colleges, the research achievement also belongs to the 085 Project of Universities in Shanghai

\section{References}

[1] Caves, R.E. and Porter, M.E. (1976) Barriers to Exit. In: Qualls, P.D. and Masson, R., Eds, Essays on Industrial Organization in Honor of Joe S. Bain. Ballinger, Cambridge, 36-69.

[2] Boddewyn, J.J. (1979) Foreign Divestment: Magnitude and Factors. Journal of International Business Studies, 10, 2126.

[3] Hamilton, R.T. and Chow, Y.K. (1993) Why Managers Divest-Evidence from New Zealand's Largest Companies. Strategic Management Journal, 14.

[4] M. C. Mcdermott (1994) Defensive Voluntary Foreign Divestment Theory and Empirical Evidence of US MNEs in the European Union. United Kingdom AIB Annual Conference, UMIST, Manchester, Mimeo.

[5] Chen, X. (2012) It Is Not Easy for America to Go Back-Interview of He Man of Transnational Corporation Research Center, Ministry of Commerce Research Institute. Equipment Manufacturing, 10.

[6] Lu, Y. (2013) Manufacture Industry Reflow to America Can’t Be Finished in One Day. Beijing News.

[7] Mi, J.W. and Chen Q. (2012) Reason and Influence of America Manufacture Industry’s Back to the Nest. Development Research, 12.

[8] Zhang, Y.Y. and Liu, D.L. (2013) Restores Outsourcing: New Strategy of Chinese Economic Globalization. Chinese Industrial Economy, 5.

[9] Liu, J.H. (2011) Back to America? Business Week, 24.

[10] Jin, B., Li P.F. and Liao J.H. (2013) Current Situation and Development Trend of China’s Industry International Competitive-Based on Analysis of Export Commodities. Chinese Industrial Economy, 5.

[11] Tian, W. and Yu, M.J. (2013) Export Strength and Liberalization of Import Intermediate Goods Trade: Empirical Research from Chinese Corporations. Management World, 1. 